\title{
Unravelling managerial competencies and the profitability of small technology-oriented businesses: A case of public access venues in an emerging economy
}

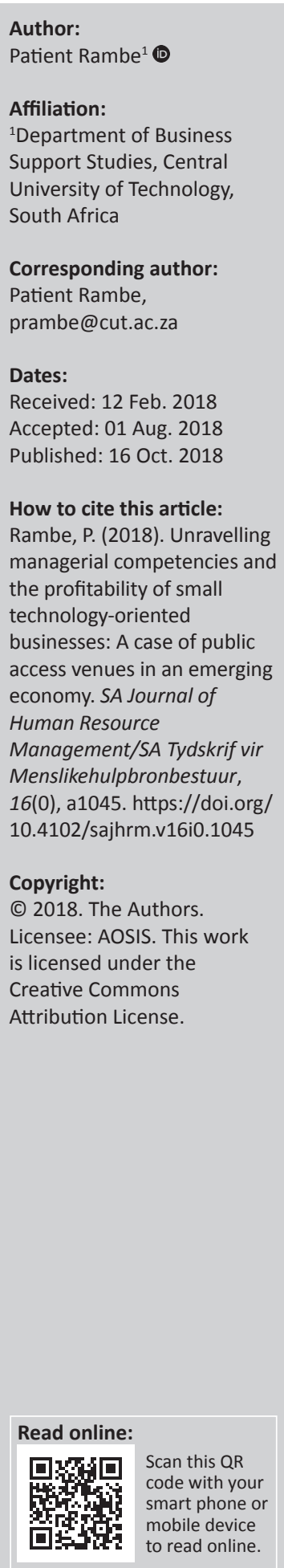

Orientation: The tweak speed of technological changes, volatility of domestic markets, shifts in consumer behaviour and homogeneity of Internet-based services are pressurising entrepreneurs operating small technology-oriented businesses such as public access venues (PAVs) (e.g. Internet cafés) to develop a compendium of managerial competencies to deal with these challenges effectively and expeditiously. Yet rigorous research on managerial competencies of Internet café business owners or managers in emerging economies such as South Africa is conspicuously missing, raising critical questions about the perceived significance of such competencies in management and entrepreneurship literature.

Research purpose: This research, therefore, examined the managerial competencies discernible among PAV or Internet café owner or managers and their implications for the profitability of their businesses.

Motivation for the study: To establish the managerial competencies of PAV or Internet café business owners or managers and their effect on the profitability of their businesses.

Research approach/design and method: Drawing on a quantitative approach and a survey design, a structured questionnaire was administered to 152 Internet café owners or managers to establish the influence of their managerial competencies on the profitability of their businesses.

Main findings: Three assortments of managerial competencies were evident among Internet café owners or managers, namely, resource management, innovation management and market management capabilities. The results of the Pearson's correlations revealed that managerial competencies are significantly correlated to business profitability, resource management capabilities have the highest correlation with profitability (Correlation $=0.743, p=0.000$ ), followed by innovation management capabilities (Correlation $=0.732, p=0.000$ ) and lastly marketing management capabilities (Correlation $=0.695, p=0.000)$.

Practical/ managerial implications: Because many businesses were very small establishments, employing less than six employees and with owners or managers who had less than 6 years of experience, it would be critical to establish if the provision of management training to owners or managers from the inception of the business would increase the growth orientation of such businesses. Because resource management capabilities have the highest correlation with firm profitability, the managerial training of small business owners or managers should concentrate more on this dimension compared to other managerial capabilities to improve their competitiveness.

Contribution/value-add: Strategic interventions to improve the profitability of these small technology-oriented businesses border on scrupulously addressing and aligning their resource management, innovation management and market management capabilities.

\section{Introduction and problem statement}

Small, micro and medium enterprises (SMME) in emerging economies such as South Africa are confronted with momentous 21st-century challenges with a strong bearing on their managerial competencies and capacities. These challenges include the global supremacy of information and communication technologies (ICTs) in the provision of products and services (Jerald, 2009; Selywn, 2016), and the volatility of the domestic market in light of the instability of domestic 
currencies (Butler, 2016; Maveé, Perrelli, \& Schimmelpfennig, 2016). Other challenges include shifts in consumer behaviour and needs (Urban, 2010) and the increasing convergence and homogeneity of Internet-based services (Powell, 2007; Rambe, 2013). These constraints cast aspersions on the capacity of small technology-oriented businesses such as Internet cafés to survive without a transformation of their owners' managerial competencies and capabilities. While the increasing permeation of ICTs into all spheres of society in the 21st-century (Jerald, 2009) has heightened the need for entrepreneurs' recognition and anticipation of technology opportunities (Urban, 2010), there is insufficient evidence on the rethinking of SMME's managerial competencies and capabilities to tap into these opportunities. Similarly, while the avalanche of bite-sized communications embedded in digital technologies are expanding and intensifying care work and emotional labour (Selwn, 2016), these promises and hype about technology cannot be sufficiently tapped into because of the paucity of managerial competencies that persist in South African small businesses to optimise the business opportunities created by technology (Nkosi, Bounds, \& Goldman, 2013; Olawale \& Garwe, 2010; Tangwo, 2012; Van Scheers, 2011).

While the SMME owners or managers' possession of managerial competencies is generally considered as critical to the creation, growth and longevity of small businesses (Nkosi et al., 2013; Temtime \& Pansiri, 2005), no systematic research has targeted technology-oriented businesses such as public access venues (PAVs), especially Internet cafés in developing countries. The few exceptions that focused on managerial competencies have not necessarily covered Internet cafés (Temtime \& Pansiri, 2005; Yahya \& Elsayed, 2012) and ironically those that foregrounded Internet cafés were theoretical studies (Rambe \& Makhalemele, 2016; Rambe \& Mokgosi, 2016) which insights lacked empirical evidence. More so, despite the professed significance of Internet cafés in ICT-based service provision, their impact in the marketplace (including the honing of managerial competencies) remains practically unknown (Dammert, Galdo, \& Galdo, 2014). As such, what remained speculative in entrepreneurship and management studies that examine managerial competencies in technology-enabled contexts is the nature of managerial competencies inherent in Internet café owners or managers and their implications for the profitability of such businesses. As such, the study attempted to address the following questions:

- Which managerial competencies are discernible among owners or managers operating small technology businesses (i.e. Internet cafés) in the Free State province?

- What is the relationship between managerial competencies of owners or managers of small Internet businesses (i.e. Internet cafés) and the profitability of their businesses?

- Which managerial competencies of owners or managers have the greatest impact on the profitability of Internet cafés in the Free State province?

\section{Problem background}

The need to explore the managerial capabilities of owners or managers of PAVs such as Internet cafés should be conceived in light of limited digital competencies and skills of some Internet café users and the uniqueness of Internet café services. These issues are discussed in subsequent sections.

\section{Parochial digital competencies and skills}

Internet cafés in South Africa render a wide spectrum of services and digital competencies to users such as the downloading and uploading of documents, browsing websites, emailing and document processing. For example, Internet café employees normally provide valuable services and support in computer use and information access to inexperienced users (Furuholt \& Kristiansen, 2007). Despite these claims, there is no guarantee that such service providers possess sophisticated technological skills and digital competencies, founded on their possession of a compendium of managerial competencies. Chen, Paik and McCabe's (2014) investigation of the Internet users' practices and perceptions of Internet security in Ghana revealed their limited comprehension of the operation of Internet technologies. They elaborate on such users' exclusive dependence on passwords for online information security and their reliance on ad hoc practices such as word of mouth to augment their knowledge of Internet security. The author infers from this that the technological savviness and exposure of Internet café owners or managers do not necessarily constitute sophisticated technological and managerial competencies relevant and critical to users' acquisition and transfer of technological skills.

\section{The peculiarity of Internet café services}

The demands for sophisticated managerial competencies among Internet café owners or managers stem from the emporium of services provided by these small firms. Makhalemele (2016) claims that the uniqueness of Internet cafés stems from the diversification of their product or service offerings, which includes Internet surfing, photocopying, retail services in addition to dining and bar services. Their services also sprawl across various geographical spaces ranging from downtown shops, airport facilities, industrial sites, suburban and peri-urban areas. Such spatial distribution presents complex temporal and spatial challenges (e.g. dealing with rivals in proximity, and time management), which demand solid managerial competencies to deal with to ensure the competitive provision of products or services.

\section{Literature review}

\section{Public access venues}

For Wijaya and Polina (2014), PAVs describe spaces that provide public access computing and therefore provide ICT and Internet access in public spaces such as Internet cafés, public libraries, hospital waiting rooms, malls and airport 
terminals. Although public agencies (e.g. government departments) often provide such information access points geared at rendering easy affordable Internet and computing services (e.g. Internet, photocopying, printing, word processing, retail and dining), non-governmental organisations and small-scale businesses are now rendering such services. Wijaya and Polina (2014) elaborate that PAVs are envisaged to play a fundamental role of bestowing access to information for underserved communities, especially those individuals without ICT and Internet connections. Augmenting public access to Internet and ICT services is particularly acute to South Africa where multiple regional (e.g. provincial divide), spatial (workhome divide) and temporal variations (within or outside education institutions) persist in access to such services. Statistics South Africa's General Household Survey (2014) highlights the heavy concentration of Internet services in the metropolitan provinces of Western Cape, Gauteng and the Free State. The same survey also reports that only one-tenth of South African households have access to the Internet at home and such access is highest in the Western Cape (23.8\%) and Gauteng (17.3\%) (see https:/// news / telecoms / 127450-internet-access-in-south-africabest-and-worst-provinces.html). To further compound this challenge, these variations also persist between rural and urban areas, between different gender groups and across different times and temporal zones. In view of these divides, the managerial competencies of owners or managers of Internet cafés, public spaces for increased access for the socio-economically marginalised, including the competitiveness of such firms, cannot be taken for granted.

\section{Studies on Internet access}

Studies on Internet access via Internet cafés have emphasised their utilisation for job searches and applications (Dammert et al., 2014), the inculcation of computer literacy among marginalised groups in informal urban slums (Hansson \& Wihlborg, 2011) and the unravelling of gender variations in university students' intentions of and behaviours when visiting Internet cafés (Hsu \& Chuang, 2008). However, an incommensurate attempt has been made to explore the intersection between Internet cafés and managerial competencies of their owners or managers. Research that has approached this intersection closest includes Temtime and Pansiri's (2005) exploration of the managerial competency and organisational flexibility of Botswana SMMEs, which reported that the critical managerial factors affecting the development of SMMEs are human resources development; organisational development, managerial background; managerial leadership and competitive strategy. Nonetheless, their study was not anchored in technology-oriented businesses per se. Bouazza, Ardjouman and Abada (2015) and Aylin, Garango, Cocca and Bititchi (2013) attribute the growth of SMMEs to the proper application of a set of managerial competencies while the paucity of such competencies is considered to hinder firm growth. Although the study by Bouazza et al. (2015) elaborates on the distinction between managerial competencies, managerial capacities and managerial competencies, this study was conducted in Algeria and did not explore Internet cafés in particular.

\section{Definition of managerial competencies}

The concept of managerial competencies cannot be sufficiently comprehended without grasping competencies. For Jauhari (2006, p. 123), competencies refer to 'observable and applied knowledge, skills, and behaviour that create a competitive advantage for an organisation'. As such, managerial competencies describe those demonstrable knowledge, skills, abilities and behavioural traits that an owner or manager of an Internet café should possess to effectively accomplish their entrepreneurial and managerial duties to generate financial value for the organisation. Fejfarová and Urbancová (2015, p. 111) define managerial competencies as 'a specific type of individual competencies; for example, specific knowledge, abilities, skills, traits, motives, attitudes and values necessary to improve management performance'. Implicit in this definition is the possession and effective application of psychological, technical and emotional dispositions relevant to task performance, which ultimately ensure organisational effectiveness. Therefore, managerial competencies are a combination of the manager's professional knowledge, acquired skills, experience, traits and the proper attitude and motivation to act on-the-job (Szczepa ska-Woszczyna, 2014). These are internal capabilities that people bring to their jobs, which may be expressed in a broad and even infinite array of on-the-job behaviours and enable successful performance of the job. The contemporary concept of managerial competencies is broad, closely related to human capital and encapsulates talents, predispositions, interests, internal motivation, education, knowledge, professional experience, practical skills, attitudes, behaviours, characteristics and the right to act on behalf of the organisation (Oleksyn, 2010; Szczepańska-Woszczyna, 2014).

\section{Typologies of managerial competencies}

Managerial competencies have generally been described differently depending on different disciplinary, functional, industrial and contextual areas. For instance, the knowledge skills and capabilities demanded in information system and ICT domains may differ from those expected in other domains, the same way skills and competencies demanded in large corporations could vary from those expected of small organisations. However, some skills, such as time management and leadership skills can be conceived as generic across different organisations regardless of size, location and industry. Nolan, Conway, Farrell and Monks (2010) describe eight competency areas ranging from professional knowledge or operational, interpersonal, communication, information technology, human resources, finance, sales and marketing skills. From an ICT perspective, Peppard and Ward (2004) formulated 26 information systems (IS) competencies falling into a nomenclature 
covering strategy formulation, specifying information technology (IT) needs and capabilities, IT delivery solutions and fostering and maintaining good relationships with suppliers. Cragg's $(2002,2008)$ study of managerial factors and their related IS competencies emphasised competencies such as business strategy, IS strategy alignment, technology innovation, technology analysis, system and process innovation and managing change. In a masters study that examined competencies of emerging technology firms in South Africa, Makhalemele (2016) identified three main competencies that are most critical: innovation management capabilities, market management capabilities and resource management competencies. Consistent with her analysis, the following sections discuss this typology of managerial competencies.

\section{Innovation management competencies}

Innovation management competencies cannot be grasped fully without defining innovation. Szczepańska-Woszczyna (2014, p. 14) defines innovation as the implementation of new ideas and introducing new solutions into practice in the environment'. Innovation, on the one hand, involves the successful execution and sometimes commercialisation of creative ideas in a business context.

Innovation management capabilities, on the other hand, describe the capacity of the firm to effectively manage its internal innovations in ways that optimise its performance and create value for the firm. Therefore, innovation management capabilities involve those capabilities required in the innovation value chain, that is, the entire innovation process ranging from the innovation input (supplies, materials and resources), innovation process (administrative procedures and techniques applied to the processes of transforming input into output) to innovation output (products, services and logistics) (Barosa \& Cintra, 2012). Depending on the size, scale of operations, industry and broad context the firm operates in, innovation management capabilities may take the form of accepting changes in product design, marketing, network management and supply chain management systems, creative thinking about products and services and the successful management of change (Quinn, Faeman, Thompson, \& McGrath 2007; Ziębicki, 2011). Innovation management capabilities also entail system-wide competencies that cover improvements in information systems, technological innovations, research and development (R\&D) activities and the clientele affairs of an organisation (Laakso-Manninen \& Viitala, 2007). It implies the application of creative problem-solving skills to develop solutions to organisational problems and adopting 'smart' risks during decision making (State of North Dakota Competency Library, n.d.) while fostering the personal development of employees through successful creative participation in organisational activities (Königová, Urbancová, \& Jiří, 2012). While small Internet firms are often constrained financially and in terms of human capital to participate in R\&D activities and to rollout wide-scale technological innovations, they are more predisposed to engage in creative problem-solving to address problems peculiar to their size and scale of operations.

In the service industry, including Internet cafés, innovation management competencies can translate into firms' foresight to 'think for the customer' by creating services that offer superior value to the customer through leveraging knowledge resources and specific stakeholder relationships (Kandampully, 2002). Therefore, innovation management competencies have the potential to improve products, services, processes and transform organisational structures. In the view of Walker, Damanpour and Devece (2011), these competencies allow the firm to achieve production and marketing goals, improve product or service quality, lower their operational costs, increase their market share, attain production flexibility and improve the management process.

\section{Market management capabilities}

Market management capabilities are a bundle of market, human resources and organisational competencies, which a business employs to access, retain and augment its customer base through the generation, dissemination and articulation of customer value. These capabilities have evolved over a long history even though the theme of creating and retaining satisfied customers remains central to the advancement of market management competencies (Day 1994; Narver \& Slater 1990). Often articulated under the banner of market orientation, market management competencies emphasise a clear recognition of the superiority of target customers (Day, 1994), the capacity of the firm to generate, disseminate and deploy superior information about customers and competitors (Kohli \& Jaworski, 1990) and the creation of superior customer value through the coordination of firm's resources (Narver \& Slater, 1990).

Since the 1990s, market management capabilities have evolved from creating satisfied customers to appropriately managing the marketing process, which includes analysing market opportunities, formulating clear marketing objectives and developing a marketing strategy that should be implemented and controlled (Kotler, 2004). Such a determination of the marketing process involves ascertaining whether and the extent to which a firm is effectively managing market research, marketing strategy, planning and implementation, control and evaluation (Banterle, Cavaliere, Stranieri, \& Carraresi, 2009). Managing market research involves capacity of the firm to locate good partners in an investment destination market, possession of adequate market knowledge of the targeted country market, development of export competencies and knowledge of the market language and cultural differences (Brancatisano, Jurriëns, \& Verburg, 2012). For Banterle et al. (2009), marketing strategy entails the formulation of marketing objectives and organising activities consistent with opportunities opened in the market. Planning and implementation is integral to the success of the marketing 
management process in the same way formulation of a marketing plan is critical to the achievement of marketing strategy objectives. Control and evaluation revolve around determining the extent of success of the outcomes of the marketing activities in terms of sales and profit.

Drawing on Day's (1994) conception of a market-driven firm and the ever evolving conception of marketing which now incorporates networking competencies and collaborative capabilities, Ritter (n.d.) conceives marketing management process as encompassing market making and market prioritising as additional capabilities. Ritter (n.d.) summarises the marketing management process as involving four main processes, namely, market sensing, market relating, market prioritising and market making. Often articulated as market orientation (Jaworski \& Kohli, 1993; Narver \& Slater, 1990), market sensing encompasses market intelligence to grasp the dynamics of the market operations. This process of knowledge management involves acquiring, sifting and synthesising information with a view to improve the performance of the business. This capability entails the business' exploitation of its current knowledge of markets (e.g. customer preferences and tastes, potential and actual competitors and partners) and its capacity to generate new knowledge that favourably positions it strategically in its chosen markets (Hou \& Chien, 2010).

Market relating involves attracting and strengthening the business' relations with the market and its customers. For Ritter (n.d.) market relating encapsulates the process of building bridges between the business and actors in the environment such as customers, suppliers, research institutions and government. This has also been perceived as relationship marketing (Berry, 1983; Berry \& Parasuraman, 1991) and transaction marketing (Coviello, Brodie, Danaher, \& Johnston, 2002) covering the creation of strong bonding ties and other distant relationships. Such relationships can be founded on logistics planning competencies geared at reducing distribution cost and improving customer satisfaction by providing products at the right place in the right condition at the right time (Christopher, 2003; Dubey \& Ali, 2011).

Market prioritising involves the selection and prioritising of important individual and group customers on a transactional basis as not all customers are equally important. Lastly, marketing making is founded on the instability of the market, its networks and a lack of a predetermined structure of operations. This gives rise to the need for the business to provide innovative offerings continually, maintain the dynamics of standardised markets and creating new niches through challenging the logics of the market. Therefore, these market management capabilities transcend the firm's capacity to demonstrate responsiveness to customers' needs to generate market innovation and attain a competitive advantage (Dubey \& Ali, 2011; Nguyen, 2008). Internet cafés may not be good candidates for market prioritising as a result of the small client base they serve and their low resource base, which undermine their logistics planning and implementation.

\section{Resource management capabilities}

Resource management capabilities cannot be grasped fully without articulating what resources, resources management and capabilities are. Resources can be conceived as organisational assets - that is (diverse physical and organisational) endowments the business has accumulated (e.g. investments in the scale, scope and efficiency of facilities and systems; brand equity; and the consequences of the location of activities for factor costs and government support) (Day, 1994). These resources range from tangible resources (e.g. physical IT infrastructure), human IT resources (e.g. technical IT skills and managerial IT skills) and intangible ITenabled resources (knowledge assets, customer orientation and synergy) to valuable resources (helping an organisation to create or implement strategies that improve its efficiency and effectiveness). Lastly, resources are rare when more organisations want them than are able to obtain them, imperfectly imitable and non-substitutable when they are immobile and expensive to imitate or replicate (Barney \& Hesterly, 2006; Bharadwaj, 2000).

In a narrow sense, resource management entails fiscal resource management, that is, the capacity of employees to effectively carry out the responsibility for planning, raising, allocating, spending and managing monetary resources to complete individual, group, unit or department, or organisation-wide work activities (State of North Dakota Competency Library, n.d.). From a human resources perspective, resource management involves developing a more integrated and well-coordinated approach to designing improvements to human resource management systems, job redesign, recruitment, organisational learning, career management, performance improvements and compensation systems (UNIDO, 2002). In its broad sense, it covers planning, project and budget management, information management, change management and organisational performance assessment (Krajcovicova, Caganova, \& Cambal, 2012).

Capabilities can be conceived as the adhesive which brings organisational assets together and enables them to be deployed as a source of competitive advantage (Day, 1994). While assets can be assigned monetary value, capabilities cannot, as they are deeply embedded in organisational routines and practices and cannot be traded or imitated (Day 1994; Dierckx \& Cool 1989). Therefore, resource management competencies describe those competencies that enable the well-coordinated and integrated deployment of financial, physical, human, organisational resources (e.g. quality control systems, corporate culture, and relationships) and technological and intangible resources (e.g. reputation, brand recognition, and goodwill) (Braganza, Brooks, Nepelski, Ali, \& Moro, 2017; Grant, 1991; Mahoney \& Pandian, 1992) to increase the competitive advantage of the firm. Based on this, the resource domains that could be most relevant to Internet 
cafés include human resources, finance (including fund raising) and organisational changes because of the size and scale of their operations.

\section{Profitability}

Profitability is one of the prominent measures of business performance. Small business owners seek to achieve profit and other economic benefits (e.g. increasing revenue and employment levels) through bearing calculated market risks (Carland, Hoy, Boulton, \& Carland, 2007; Ndofirepi, 2016). The common measures of profitability include sales revenue, gross profit, net profit, percentage return on investment and an increase in employment figures (Gumbochuma, 2017).

\section{Methodology}

This study adopted a cross-sectional survey design and drew on a structured questionnaire, which was developed based on an in-depth examination of literature on managerial competencies and their impact on firm performance. A crosssectional survey design allows the researcher to develop a set of statements that characterise the individual or groups, aimed at collecting data about these individuals or groups at a particular point in time as opposed to at intermittent intervals (Privitera, 2013; Punch, 2013). Because the researcher was preoccupied with exploring the managerial competencies discernible among Internet café owners or managers at a particular point in time and how these relate to firm profitability, the cross-sectional survey design was conceived as most appropriate for this study.

\section{Target population and sampling}

A target population describes 'the total group of individuals from which a sample is drawn' (Dzansi, 2014, p. 28). Officials from the Free State Development Corporation (FDC), a funding agency for Internet cafés, estimated that there were approximately 250 Internet cafés in the Mangaung Metropolitan Area including outlying areas in the Free State province. It is important to emphasise that although individual owners or managers were the appropriate unit of analysis because of the study's focus on their managerial competencies, FDC only provides the list of SMMEs and not their owners or managers per se. Hence, a critical point of departure was to employ this list to calculate the number of SMMEs for inclusion in the sample and subsequently work with the owners or managers of these selected firms. Using a sample size calculator set at $95 \%$ confidence level and a margin of error of 5\% (https://www.surveysystem.com/ sscalc.htm), the researcher established that for a population of 250 SMMEs, 152 units will be required for sufficient analysis. As such, owners or managers of 152 Internet cafés located in the Free State province were interviewed for further investigation.

Because the researcher assumed variations in Internet cafés in the metropole, cities, towns and small towns, stratified sampling which involves dividing the wider population into homogenous or discrete groups, that is, strata (Cohen,
Manion, \& Morrison, 2010) was employed. This was followed by the random sampling within these groups or strata, the size of each group being determined by the judgement of the researcher (Cohen et al., 2010). Consistent with the idea of distributing more questionnaires to areas with more Internet cafés, 50 questionnaires were distributed in Bloemfontein, Thaba-Nchu received 20 questionnaires, while Botshabelo received 27, Welkom 17, Harrismith 25 and Qwa-Qwa 13, for representivity purposes.

\section{Measuring instrument, data collection and analysis}

As indicated, a structured questionnaire was developed based on an in-depth examination of literature relating the managerial competencies of SMMEs with a technology orientation. In view of the reality that most research instruments on competencies were prepared for small businesses in general and not technology-oriented SMMEs in particular (which have unique characteristics - offering intangible technology services, serve a particular clientele with a technological orientation, predominantly middle class and students), a new instrument was necessary.

In view of the diverse literature covering multiple competencies, only those innovation management competencies related to and feasible for small technologyoriented firms were considered in the development of the questionnaire. These included creative thinking about products and services, successful management of change (Quinn et al. 2007; Ziębicki, 2011), improvements in information systems and technological innovations (Laakso-Manninen \& Viitala, 2007), creative problem-solving skills to develop solutions to organisation problems (State of North Dakota Competency Library, n.d.) and personal development of employees through successful creative participation in an organisational activity (Königová et al., 2012).

Market management competencies considered included analysing market opportunities, formulating clear marketing objectives, developing a marketing strategy (Jaworski \& Kohli, 1993; Kotler, 2004), effectively managing market research, (Banterle et al., 2009; Brancatisano et al., 2012) and implementation of marketing management processes (Banterle et al., 2009) including market training of employees. Control and evaluation were not included because most Internet cafés often lack the financial resources, expertise and training to effectively execute such processes because of their survivalist orientation and lack of a growth-oriented approach to firm sustainability. Shuman and Seeger (1986) and Alcantar and Ngwenyama (2015) argue that although large and small companies deal with many of the same issues, smaller businesses also deal with unique size-related challenges, and they behave differently in their analysis of and interaction with their environments.

The resource management capabilities included developing human IT, technical and managerial skills (Barney \& Hesterly, 2006; Bharadwaj, 2000), improvements in human resource 
recruitment systems (UNIDO, 2002), budget management, change management (Krajcovicova et al., 2012) and management of intangible organisational resources (Braganza et al., 2017; Mahoney \& Pandian, 1992).

Because the main business of Internet cafés is the provision of Internet, photocopying, printing and other web-based services in addition to sale of Internet related products (e.g. flash drives, compact disks [CDs], speakers and electronic gadgets), improvements in sales, profit margins, salaries and meeting financial targets were the main measurements of profitability in this study.

Likert-based close-ended questions were developed. The questionnaire had four sections covering owner or manager demographics, business profile, different managerial competencies and firm performance.

With the assistance of two research assistants, data were collected from Internet café owners or managers located in the Free State province. The Free State was large enough to provide a fair representation of various racial groups in South Africa. The data were collected over a period of 2 months.

Data were coded, captured into Microsoft Excel, cleaned and exported to Statistical Package for the Social Sciences Version 21 for detailed analysis. While frequencies verified the coding of the data, descriptive analysis assisted in comparing and describing the data. Inferential statistics, specifically correlation and regression analysis, were employed to establish relationships between managerial competencies and profitability and to predict the strength and effects of these relationships.

\section{Validity of the instrument}

Principal component analysis (PCA) was carried out on each of the elements that sought to measure each of the four variables, namely, innovation management capabilities, marketing management capabilities, resource management capabilities and profitability of the business (see Table 1 for the factor loadings for each variable).

The Kaiser-Meyer-Olkin (KMO) values derived are greater than 0.7, which is more than the minimum acceptable threshold of 0.5 (Field, 2009), validating the sampling adequacy for the analysis. Furthermore, the result of $p<0.001$ for Bartlett's test of sphericity demonstrates that correlations between items were sufficiently large for PCA. A factor loading value greater than 0.5 shows a relationship between the individual measuring items constituting a variable (factor). The structural validity results for each of the variables, and the subsequent factor analysis, are reported in Table 2 . The results of the factor analysis suggest that all questionnaire elements intended to measure the four constructs and should be retained. These include innovation management capabilities, marketing management capabilities, resource management capabilities and profitability.
TABLE 1: Principal component analysis.

\begin{tabular}{|c|c|}
\hline Component & Loading \\
\hline \multicolumn{2}{|l|}{ Innovation management capabilities } \\
\hline $\begin{array}{l}\text { My business imparts technological knowledge on its } \\
\text { employees to produce new products or services. }\end{array}$ & 0.878 \\
\hline $\begin{array}{l}\text { My business values the skills of introducing new business } \\
\text { systems frequently. }\end{array}$ & 0.830 \\
\hline $\begin{array}{l}\text { My business encourages the development of unique skills } \\
\text { among its employees for marketing its products or services. }\end{array}$ & 0.911 \\
\hline $\begin{array}{l}\text { My business encourages its employees to engage in creative } \\
\text { thinking about the development of its products or services. }\end{array}$ & 0.881 \\
\hline $\begin{array}{l}\text { My business employs participative decision making on the } \\
\text { purchase of new stock or products. }\end{array}$ & 0.872 \\
\hline $\begin{array}{l}\text { My business develops unique ideas and creatively transforms } \\
\text { existing products into better products. }\end{array}$ & 0.775 \\
\hline \multicolumn{2}{|l|}{ Marketing management capabilities } \\
\hline $\begin{array}{l}\text { The business uses market research knowledge on customer } \\
\text { preferences when making decisions about amount of service } \\
\text { to provide to them. }\end{array}$ & 0.875 \\
\hline $\begin{array}{l}\text { The business frequently explores the size of the market before } \\
\text { launching a new product or service. }\end{array}$ & 0.895 \\
\hline $\begin{array}{l}\text { The business equips its employees with marketing skills (i.e. } \\
\text { training) before promoting its products or services. }\end{array}$ & 0.868 \\
\hline $\begin{array}{l}\text { The business engages in systematic planning before marketing } \\
\text { its products or services. }\end{array}$ & 0.888 \\
\hline \multicolumn{2}{|l|}{ Resource management capabilities } \\
\hline $\begin{array}{l}\text { The business selects its employees based on their experience, } \\
\text { qualifications or skills. }\end{array}$ & 0.731 \\
\hline $\begin{array}{l}\text { The business is capable of raising funds for the purchase of its } \\
\text { working equipment, products or service. }\end{array}$ & 0.795 \\
\hline $\begin{array}{l}\text { The business owner or manager (i.e. myself) had much } \\
\text { knowledge of the need for start-up capital when she/he } \\
\text { started the business. }\end{array}$ & 0.777 \\
\hline $\begin{array}{l}\text { The business uses skilled employees to facilitate systemic } \\
\text { changes in its organisation. }\end{array}$ & 0.877 \\
\hline $\begin{array}{l}\text { The business owner or manager displays leadership qualities } \\
\text { which guide employees in achieving the set goals. }\end{array}$ & 0.701 \\
\hline \multicolumn{2}{|l|}{ Profitability } \\
\hline My profit margins have increased in the last 3 years. & 0.919 \\
\hline I have been able to generate profit for the last 3 years. & 0.920 \\
\hline $\begin{array}{l}\text { The business is driven by a need for continuous improvement } \\
\text { of its products and services to raise its profitability. }\end{array}$ & 0.711 \\
\hline $\begin{array}{l}\text { I was able to meet my annual financial targets in the } \\
\text { past } 3 \text { years. }\end{array}$ & 0.699 \\
\hline $\begin{array}{l}\text { I have been able to raise salaries and wages from profits in the } \\
\text { past } 3 \text { years. }\end{array}$ & 0.889 \\
\hline
\end{tabular}

TABLE 2: Results of the exploratory factor analysis.

\begin{tabular}{lccc}
\hline Dimension & KMO statistic & $\begin{array}{c}\text { Bartlett's } \\
p \text {-value }\end{array}$ & $\begin{array}{c}\text { Cumulative \% of } \\
\text { variance explained }\end{array}$ \\
\hline $\begin{array}{l}\text { Innovation management } \\
\text { capabilities }\end{array}$ & 0.728 & 0.000 & 78.200 \\
$\begin{array}{l}\text { Marketing management } \\
\text { capabilities }\end{array}$ & 0.896 & 0.000 & 73.766 \\
$\begin{array}{l}\text { Resource management } \\
\text { capabilities }\end{array}$ & 0.851 & 0.000 & 77.701 \\
\begin{tabular}{l} 
Profitability \\
\hline
\end{tabular} & 0.830 & 0.000 & 60.597 \\
\hline
\end{tabular}

KMO, Kaiser-Meyer-Olkin.

\section{Reliability of data}

Reliability is the extent to which an instrument is repeatable and consistent across time (Pietersen \& Maree, 2014). A statistician in liaison with the researcher, assisted with the pretesting of the questionnaire and its validation. The results of the reliability test are summarised in Table 3.

Adequate reliability of a construct is indicated by a Cronbach's Alpha value of at least 0.700 . The fact that all constructs in the questionnaire had Cronbach's Alpha coefficients greater than 0.700 demonstrate high internal 
TABLE 3: Questionnaire reliability statistics.

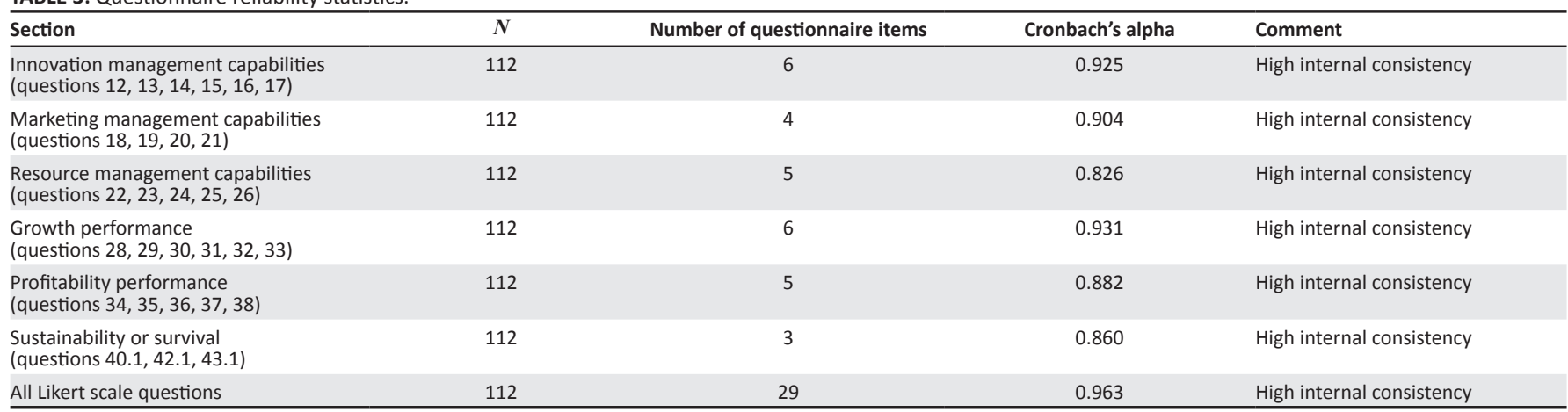

$N$, number.

TABLE 4: Biographical information.

\begin{tabular}{|c|c|c|c|}
\hline Personal details & Category & Frequency & Percentage \\
\hline \multirow[t]{2}{*}{ 1. Gender } & Male & 36 & 32.1 \\
\hline & Female & 76 & 67.9 \\
\hline \multirow[t]{5}{*}{ 2. Age group } & Less 25 years & 21 & 18.8 \\
\hline & $25-34$ & 57 & 50.9 \\
\hline & $35-44$ & 22 & 19.6 \\
\hline & $45-54$ & 11 & 9.8 \\
\hline & 55 and above & 1 & 0.9 \\
\hline \multirow[t]{6}{*}{ 3. Home language } & English & 12 & 10.7 \\
\hline & Afrikaans & 6 & 5.4 \\
\hline & Sesotho & 56 & 50.0 \\
\hline & IsiZulu & 11 & 9.8 \\
\hline & IsiXhosa & 16 & 14.3 \\
\hline & $\begin{array}{l}\text { Other language } \\
\text { (specify) }\end{array}$ & 11 & 9.8 \\
\hline \multirow[t]{5}{*}{ 4. Qualification } & None & 1 & 0.9 \\
\hline & Matric and below & 45 & 40.2 \\
\hline & FET or equivalent & 37 & 33.0 \\
\hline & $\begin{array}{l}\text { University degree or } \\
\text { diploma }\end{array}$ & 18 & 16.1 \\
\hline & Postgraduate & 11 & 9.8 \\
\hline \multirow[t]{6}{*}{ 5. Level of training } & None & 33 & 30.0 \\
\hline & Short courses & 39 & 35.5 \\
\hline & Apprenticeship & 2 & 1.8 \\
\hline & High school & 5 & 4.5 \\
\hline & Undergraduate & 22 & 20.0 \\
\hline & Postgraduate & 9 & 8.2 \\
\hline
\end{tabular}

FET, Further Education and Training

consistency, hence were reliable. The overall questionnaire is also very reliable (Cronbach's Alpha $=0.963)$.

\section{Sample demographics}

Internet café owners' or managers' demographic and business profiles are summarised in Tables 4 and 5, respectively.

Of the 112 owners or managers who responded to the survey, a majority (67.9\%) of them were women and the remaining $32.1 \%$ were men. This finding is surprising in view of the fact that men are often considered to be more technologically savvy than women. About $50.9 \%$ of the respondents were $25-34$ years old, $19.6 \%$ were aged $35-44,18.8 \%$ were under the age of 25 and $9.8 \%$ were between 45 and 54 years of age. This points to the dominance of a young adult population as owners or managers of small technology-oriented businesses.
TABLE 5: Company information.

\begin{tabular}{|c|c|c|c|}
\hline Company details & Category & Frequency & Percentage \\
\hline \multirow{3}{*}{$\begin{array}{l}\text { 6. Nature of } \\
\text { organisation that } \\
\text { you work for }\end{array}$} & Internet café & 24 & 21.6 \\
\hline & Internet and printing & 36 & 32.4 \\
\hline & $\begin{array}{l}\text { Internet, printing and } \\
\text { retail }\end{array}$ & 51 & 46.0 \\
\hline \multirow{5}{*}{$\begin{array}{l}\text { 7. Your role in this } \\
\text { business }\end{array}$} & Employee & 20 & 17.9 \\
\hline & Supervisor & 10 & 8.9 \\
\hline & Manager & 29 & 25.9 \\
\hline & Manager or owner & 8 & 7.1 \\
\hline & Owner & 45 & 40.2 \\
\hline \multirow{4}{*}{$\begin{array}{l}\text { 8. Number of years } \\
\text { served in current job }\end{array}$} & Below 1 year & 21 & 18.8 \\
\hline & $2-5$ years & 66 & 58.9 \\
\hline & $6-10$ years & 20 & 17.9 \\
\hline & $11-15$ years & 5 & 4.5 \\
\hline \multirow{4}{*}{$\begin{array}{l}\text { 9. Number of years } \\
\text { served in a } \\
\text { management } \\
\text { position }\end{array}$} & Below 1 year & 23 & 21.7 \\
\hline & $2-5$ years & 64 & 60.4 \\
\hline & $6-10$ years & 15 & 14.2 \\
\hline & $11-15$ years & 4 & 3.8 \\
\hline \multirow{6}{*}{$\begin{array}{l}\text { 10. The number of } \\
\text { employees in this } \\
\text { business }\end{array}$} & None & 8 & 7.1 \\
\hline & One & 13 & 11.6 \\
\hline & $2-5$ & 62 & 55.4 \\
\hline & $6-10$ & 23 & 20.5 \\
\hline & $11-15$ & 5 & 4.5 \\
\hline & $16-20$ & 1 & 0.9 \\
\hline \multirow{5}{*}{$\begin{array}{l}\text { 11. Highest academic } \\
\text { qualification of } \\
\text { employees }\end{array}$} & None & 6 & 5.5 \\
\hline & Matric and below & 60 & 55.0 \\
\hline & Tertiary certificate & 15 & 13.8 \\
\hline & Diploma or degree & 21 & 19.3 \\
\hline & Postgraduate & 7 & 6.4 \\
\hline
\end{tabular}

Note: Figures may not add up to $100 \%$ because of rounding off after conversion to percentages.

Sesotho owners or managers of Internet cafés were the most represented $(50 \%)$, followed by Xhosa owners or managers (14.3\%). The prominence of Sesotho-speaking owners or managers can be attributed to the fact that Basothos are the dominant group in the Free State province. A considerable percentage $(40.2 \%)$ of the owners or managers had either a matric or lower qualification, 33\% had a Further Education and Training (FET) or equivalent qualification while $16.1 \%$ had either a university degree or diploma.

\section{Company profile}

Table 5 summaries the business profile, its nature, role and duration; the number of years the owner or manager had 
been at management level; the number of employees in the business; and the qualification that the employees have.

A majority (58.9\%) of Internet café businesses had been in operation for 25 years, $18.8 \%$ of these businesses had been in operation for less than 1 year, while $17.9 \%$ of them had been in operation for between 6 and 10 years. A sizeable percentage (46\%) of the Internet cafés' core business was the provision of Internet, printing and retail services, 32\% offered Internet and printing services exclusively while the remainder served as Internet cafés only (22\%). These statistics point to the different levels of diversification of these businesses.

A sizeable proportion (40.2\%) of the respondents was owners, $25.9 \%$ were managers, $17.9 \%$ were employees and $8.9 \%$ were supervisors. Perhaps employees could have been managers and supervisors who performed limited managerial and supervisory roles and hence conceived themselves more as employees than managers and supervisors. A majority $(60.4 \%)$ of the Internet café owners or managers had between 2 and 5 years of experience of managing such firms while $21.7 \%$ of the Internet café owners or managers had less than a year of Internet managerial experience. The statistics suggest the infantile nature of most of these businesses.

\section{Results and discussion \\ Managerial competencies discernible among Internet café owners or managers}

This section addresses the question on managerial competencies discernible among owners or managers operating small technology businesses (i.e. Internet cafés) in the FreeState province. In view of the reality that competencies comprise a set of knowledge, skills and abilities possessed by an individual, some of which are hard to estimate with precision, a reasonable proxy for determining these competencies was to test them from the perspective of capabilities rather than arbitrarily asking their possession of a competency set. Capabilities related to practically oriented business processes, actions and activities these owners or managers were capable of accomplishing in their firms. The managerial competencies discernible among Internet café owners or managers were innovation management capabilities, market management capabilities and resource management capabilities.

\section{Innovation management capabilities}

The wide range of competencies encapsulating innovation management capabilities are summarised in Table 6.

\section{Imparting technological knowledge and introducing business systems}

About $84.8 \%$ of owners or managers agreed or strongly agreed that their businesses imparted technological knowledge on their employees to produce new products or services. This corroborates Rambe and Dzansi's (2016) finding that effective technology adoption demands not only the shared intentionality among a distributed core group of employees (i.e. technology implementers) at the lower rungs of the organisation but also the sufficient buy-in of senior management.

More so, $84 \%$ of the respondents were of the opinion that their businesses valued the skills of introducing new business systems frequently. This finding corroborates evidence in entrepreneurial literature on the value of infusing necessary skills such as project and business management skills in the successful conceptualisation and

TABLE 6: Innovation management capabilities.

\begin{tabular}{|c|c|c|c|c|c|c|c|c|c|}
\hline \multirow{2}{*}{$\begin{array}{l}\text { Innovation } \\
\text { management } \\
\text { capabilities }\end{array}$} & \multicolumn{6}{|c|}{ Frequency distribution } & \multicolumn{2}{|c|}{ Descriptive } & \multirow{2}{*}{$\begin{array}{c}\text { Latent factor } \\
\text { (principal } \\
\text { component) } \dagger\end{array}$} \\
\hline & Strongly disagree & Disagree & Neutral & Agree & Strongly agree & $\begin{array}{c}\text { Agree or } \\
\text { strongly agree }\end{array}$ & Mean & Std dev & \\
\hline \multicolumn{10}{|c|}{ 12. My business imparts technological knowledge on its employees to produce new products or services } \\
\hline Count & 0 & 3 & 13 & 42 & 47 & - & 4.27 & 0.79 & 0.878 \\
\hline$\%$ & 0.0 & 2.9 & 12.4 & 40.0 & 44.8 & 84.8 & - & - & - \\
\hline \multicolumn{10}{|c|}{ 13. My business values the skills of introducing new business systems frequently } \\
\hline Count & 0 & 1 & 15 & 50 & 39 & - & 4.21 & 0.72 & 0.830 \\
\hline$\%$ & 0.0 & 1.0 & 14.3 & 47.6 & 37.1 & 84.8 & - & - & - \\
\hline \multicolumn{10}{|c|}{ 14. My business encourages the development of unique skills among its employees for marketing its products or services } \\
\hline Count & 0 & 2 & 16 & 40 & 47 & - & 4.26 & 0.78 & 0.911 \\
\hline$\%$ & 0.0 & 1.9 & 15.2 & 38.1 & 44.8 & 82.9 & - & - & - \\
\hline \multicolumn{10}{|c|}{ 15. My business encourages its employees to engage in creative thinking about the development of its products or services } \\
\hline Count & 1 & 5 & 18 & 34 & 46 & - & 4.14 & 0.94 & 0.881 \\
\hline$\%$ & 1.0 & 4.8 & 17.3 & 32.7 & 44.2 & 76.9 & - & - & - \\
\hline Count & 1 & 10 & 15 & 41 & 37 & - & 3.99 & 0.99 & 0.872 \\
\hline$\%$ & 1.0 & 9.6 & 14.4 & 39.4 & 35.6 & 75.0 & - & - & - \\
\hline \multicolumn{10}{|c|}{ 17. My business develops unique ideas and creatively transforms existing products into better products } \\
\hline Count & 1 & 5 & 17 & 42 & 38 & - & 4.08 & 0.90 & 0.775 \\
\hline$\%$ & 1.0 & 4.9 & 16.5 & 40.8 & 36.9 & 77.7 & - & - & - \\
\hline
\end{tabular}

Cronbach's Alpha, 0.925

$\%$ of total variation accounted for by latent factor, 73.77

Std dev, standard deviation.

$\dagger$, coefficient. 
incubation of new business start-ups (Lindgren \& Packendorff, 2011; Ramirez-Portilla, 2013).

\section{Developing marketing skills and creative thinking}

A total of $82.9 \%$ of Internet café owners or managers affirmed that their businesses encouraged the development of unique skills for marketing its products or services. A majority (76.9\%) of owners or managers also claimed that their employees were encouraged to engage in creative thinking about the development of products and services. This mirrors the business development stages of small businesses, where employees are not only expected to generate innovative ideas but also to operationalise them through the application of business concepts by launching new products, introducing new methods of production and new marketing techniques (Dzansi, Rambe, \& Coleman, 2015; Hatten, 2006).

\section{Participative decision making in purchases and idea generation}

About $79 \%$ of the respondents agreed or strongly agreed that their businesses employ participative decision making on the purchase of new stocks or products. This view supports Liang, Huang, Lu and Wang's (2015) finding that individuals' direct participation in collective activities positively impacts organisations' economic activities. The other finding was that $77.7 \%$ agreed or strongly agreed that their businesses developed unique ideas and creatively transformed existing products into new products. However, the peculiarity of this finding is that most SMMEs such as Internet cafés do not really sell new unique products but rather engage in 'replicative entrepreneurship' (Ndofirepi, 2016) in which they market and sell already manufactured products and services.

\section{Market management capabilities}

The second set of managerial competencies is summarised under market management capabilities, which revolved around issues that are summarised in Table 7.

\section{Knowledge on customer preferences and market size}

Table 7 shows that $73.1 \%$ of the respondents agreed or strongly agreed that their businesses used market research knowledge on customer preferences when making decisions about the amount of service to provide to customers. Because entrepreneurship encapsulates innovative thinking and production of goods and services for customers to make profit while bearing the inherent risk (Agbobli, 2013; Allen, 2013), it is logical to expect Internet café businesses to be sensitive to customers' preferences and needs if they are to maximise businesses' economic value.

\section{Systematic planning before marketing their products and services}

The findings in Table 7 also demonstrate that $70.2 \%$ of the Internet owners or managers claimed that their businesses engaged in systematic planning before marketing their products and services. Because business planning entails 'formulating decisions about which practical activities to be accomplished as well as turning ideas into reality via a business plan' (Dzansi et al., 2015, p. 5), planning is deemed instrumental in providing a visual map and displaying the future state of affairs which, when correctly executed, will result in business success. This finding resonates with the claim by Gruber (2007) and Nieman and Nieuwenhuizen (2009) that systematic planning is pivotal in enhancing the entrepreneur's thinking processes about all components of the business to reduce the risks associated with business activities.

\section{Marketing skills and systematic planning}

The majority $(61.9 \%)$ of the respondents agreed or strongly agreed that their businesses equipped their employees with marketing skills before promoting their products or services. This finding seems to cohere with Agbobli's (2013) claim that resource mobilisation (including sufficient marketing training of staff) should precede the identification of markets and launch of products. Market training is critical to the

TABLE 7: Marketing management capabilities.

\begin{tabular}{|c|c|c|c|c|c|c|c|c|c|}
\hline \multirow{2}{*}{$\begin{array}{l}\text { Marketing } \\
\text { management } \\
\text { capabilities }\end{array}$} & \multicolumn{6}{|c|}{ Frequency distribution } & \multicolumn{2}{|c|}{ Descriptive } & \multirow{2}{*}{$\begin{array}{l}\text { Latent factor } \\
\text { (principal } \\
\text { component) } \dagger\end{array}$} \\
\hline & Strongly disagree & Disagree & Neutral & Agree & Strongly agree & $\begin{array}{l}\% \text { Agree or } \\
\text { strongly agree }\end{array}$ & Mean & Std dev & \\
\hline \multicolumn{10}{|c|}{ 18. The business uses market research knowledge on customer preferences when making decisions about the amount of service to provide to them } \\
\hline Count & 1 & 10 & 17 & 50 & 26 & - & 3.87 & 0.94 & 0.875 \\
\hline$\%$ & 1.0 & 9.6 & 16.3 & 48.1 & 25.0 & 73.1 & - & - & - \\
\hline \multicolumn{10}{|c|}{ 19. The business frequently explores the size of the market before launching a new product or service } \\
\hline Count & 2 & 12 & 33 & 45 & 13 & - & 3.52 & 0.92 & 0.895 \\
\hline$\%$ & 1.9 & 11.4 & 31.4 & 42.9 & 12.4 & 55.2 & - & - & - \\
\hline \multicolumn{10}{|c|}{ 20. The business equips its employees with marketing skills (i.e. training) before promoting its products or services } \\
\hline Count & 2 & 9 & 29 & 45 & 20 & - & 3.69 & 0.94 & 0.868 \\
\hline$\%$ & 1.90 & 8.60 & 27.60 & 42.90 & 19.00 & 61.90 & - & - & - \\
\hline \multicolumn{10}{|c|}{ 21. The business engages in systematic planning before marketing its products or services } \\
\hline Count & 2 & 5 & 24 & 56 & 17 & - & 3.78 & 0.85 & 0.888 \\
\hline$\%$ & 1.9 & 4.8 & 23.1 & 53.8 & 16.3 & 70.2 & - & - & - \\
\hline
\end{tabular}

Cronbach's Alpha, 0.904

$\%$ of total variation accounted for by latent factor, 77.7.

Std dev, standard deviation.

$\dagger$, coefficient. 
identification of existing and new markets, the location of market gaps and developing interventions to breach them, in addition to the development of employees' sufficient knowledge of products and services before they can market them successfully.

\section{Resource management capabilities}

A third set of managerial competencies discerned was resource management capabilities which comprised the business staff's appointment procedures, fund raising capabilities, change management strategies and the business owners or managers' capacity to demonstrate leadership. The findings on resource management capabilities dimensions are illustrated in Table 8 . This table required respondents to highlight their extent of agreement with each of the statements provided.

\section{Leadership qualities}

The findings demonstrate that a majority (86.1\%) of Internet owners or managers agreed or strongly agreed that they displayed leadership qualities that guided employees in achieving their set goals. However, Internet café managers' exercise of leadership, power and authority may vary depending on whether the manager is a member of the family that owns the business or not. The studies by Ingram and Simon (1995) and Moshavi and Koch (2005) found that nonfamily managers of SMMEs were often less capacitated to exercise leadership and exert influence, and their decisions tended to be given less weight and priority than those of family members. These variations could be attributed to the non-family managers' limited influence in decision making processes of family-owned businesses.

\section{Fund raising capabilities}

With regard to funding capabilities, the study examined the extent to which businesses were capable of raising funds for the purchase of equipment, products or services. The findings suggest that $84.8 \%$ of the owners or managers agreed or strongly agreed that their businesses had the capacity to raise such funds for the purchase of working equipment, products or services. Consistent with the resource-based view, the findings corroborate the view that firm resources (finance, skills, knowledge, experience and capabilities) are not limited to the possession of firm-specific resources but also to the effective utilisation of these resources to achieve competitive advantage (Ramorena, 2016). The current researcher argues that most Internet cafés displayed resource mobilisation capabilities as they could raise their capital with limited external support (e.g. external borrowing).

\section{Facilitating systemic organisational changes}

The findings highlight that $78.4 \%$ of the Internet café businesses owners or managers used skilled employees to facilitate systemic changes in their organisation. This finding somewhat contradicts studies in the construction industry in which highly skilled employees were largely concentrated in large organisations such as Murray and Roberts, Aveng, WBHO, Group 5 and Basil Read compared to emerging contractor firms (Construction Industry Development Board, 2015; Ramorena, 2016).

\section{Selection of employees based on their experience, qualifications or skills}

The finding that $49.5 \%$ of respondents agreed or strongly agreed that their businesses selected employees based on their experience, qualifications or skills somewhat contradicts biographic data in Table 5 that state that $55 \%$ of respondents were less educated (i.e. had a matric qualification and below). It is not clear whether this contradiction arose from respondents' slight variations with regard to the experience and skills of their employees or was a consequence of different employees judging the attainment of matric differently (e.g. as an achievement or not).

TABLE 8: Resource management capabilities.

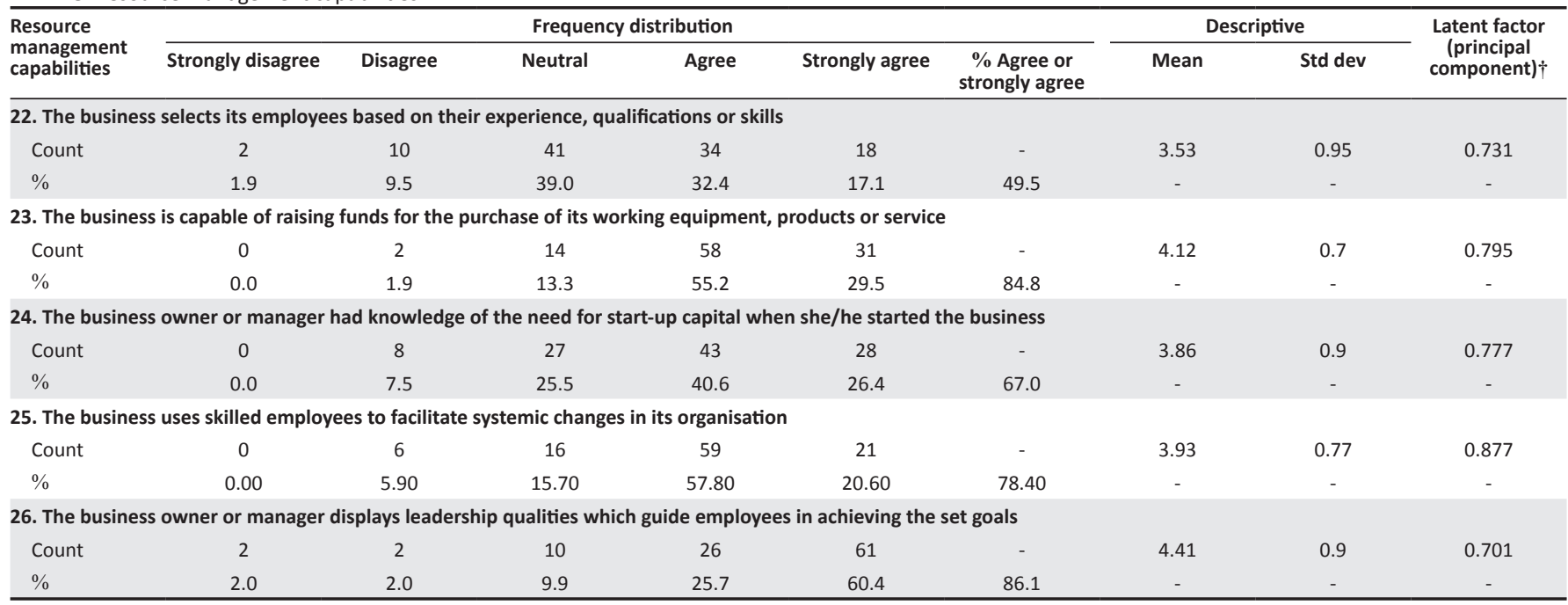

Cronbach's Alpha, 0.826 .

$\%$ of total variation accounted for by latent factor, 60.6 .

Std dev, standard deviation.

$\dagger$, coefficient. 
TABLE 9: Performance measurement - Profitability.

\begin{tabular}{|c|c|c|c|c|c|c|c|c|c|}
\hline \multirow[t]{2}{*}{ Profitability } & \multicolumn{6}{|c|}{ Frequency distribution } & \multicolumn{2}{|c|}{ Descriptives } & \multirow{2}{*}{$\begin{array}{c}\text { Latent factor } \\
\text { (principal } \\
\text { component) } \dagger\end{array}$} \\
\hline & Strongly disagree & Disagree & Neutral & Agree & Strongly Agree & $\begin{array}{l}\% \text { Agree or } \\
\text { strongly agree }\end{array}$ & Mean & Std dev & \\
\hline \multicolumn{10}{|c|}{ 34. My profit margins have increased in the last 3 years } \\
\hline Count & 0 & 2 & 26 & 44 & 29 & - & 3.99 & 0.79 & 0.919 \\
\hline$\%$ & 0.0 & 2.0 & 25.7 & 43.6 & 28.7 & 72.3 & - & - & - \\
\hline \multicolumn{10}{|c|}{ 35. I have been able to generate profit for the last $\mathbf{3}$ years } \\
\hline Count & 0 & 2 & 22 & 47 & 30 & - & 4.04 & 0.77 & 0.92 \\
\hline$\%$ & 0.0 & 2.0 & 21.8 & 46.5 & 29.7 & 76.2 & - & - & - \\
\hline \multicolumn{10}{|c|}{ 36. The business is driven by a need for continuous improvement of its products of services to raise its profitability } \\
\hline Count & 0 & 0 & 13 & 53 & 38 & - & 4.24 & 0.66 & 0.711 \\
\hline$\%$ & - & - & - & - & - & - & - & - & - \\
\hline \multicolumn{10}{|c|}{ 37. I was able to meet my annual financial targets in the past 3 years } \\
\hline Count & 0 & 17 & 40 & 31 & 14 & - & 3.41 & 0.93 & 0.699 \\
\hline$\%$ & 0.0 & 16.7 & 39.2 & 30.4 & 13.7 & 44.1 & - & - & - \\
\hline Count & 0 & 8 & 20 & 39 & 34 & - & 3.98 & 0.93 & 0.889 \\
\hline$\%$ & 0.0 & 7.9 & 19.8 & 38.6 & 33.7 & 72.3 & - & - & - \\
\hline
\end{tabular}

Cronbach's Alpha, 0.882 .

$\%$ of total variation accounted for by latent factor, 69.50

Std dev, standard deviation.

$\dagger$, Coefficient.

TABLE 10: Correlations between business profitability and managerial competencies.

\begin{tabular}{|c|c|c|c|}
\hline \multirow[t]{2}{*}{ Pearson's correlations } & \multicolumn{3}{|c|}{ Managerial competencies } \\
\hline & $\begin{array}{l}\text { Innovation } \\
\text { management } \\
\text { capabilities }\end{array}$ & $\begin{array}{c}\text { Marketing } \\
\text { management } \\
\text { capabilities }\end{array}$ & $\begin{array}{c}\text { Resource } \\
\text { management } \\
\text { capabilities }\end{array}$ \\
\hline \multicolumn{4}{|c|}{ Innovation management capabilities } \\
\hline Correlation & - & $0.767^{*}$ & $0.764^{*}$ \\
\hline$p$ & - & 0 & 0 \\
\hline$N$ & - & 95 & 93 \\
\hline \multicolumn{4}{|c|}{ Marketing management capabilities } \\
\hline Correlation & - & - & $0.782^{*}$ \\
\hline$p$ & - & - & 0 \\
\hline$N$ & - & - & 96 \\
\hline \multicolumn{4}{|c|}{ Resource management capabilities } \\
\hline Correlation & - & - & - \\
\hline$p$ & - & - & - \\
\hline$N$ & - & - & - \\
\hline \multicolumn{4}{|c|}{ Performance - profitability } \\
\hline Correlation & $0.732 *$ & $0.695^{*}$ & $0.743^{*}$ \\
\hline$p$ & 0 & 0 & 0 \\
\hline$N$ & 96 & 97 & 96 \\
\hline
\end{tabular}

*, Strong correlations

$\mathrm{N}$, number

\section{Business profitability measurements}

The highest ranking profitability attribute (87.5\% agreed or strongly agreed) was that most of the businesses were driven by a need for continuous improvement of their products or services to raise profitability. However, this finding on continuous improvement - itself a component of innovation - seems inconsistent with the lower innovation or growth effect size reported in preceding sections of this investigation. Table 9 presents results from the questionnaire items that addressed the profitability of the businesses surveyed. Most participants (72.3\%) believed that over the previous 3 years their businesses have increased their profit margins, been able to raise salaries and wages from profits $(72.3 \%)$ and have been able to generate profit $(76.2 \%)$.

\section{Relationship between managerial competencies and the profitability of emerging technology businesses.}

The relationship between managerial competencies and the profitability of emerging technology businesses is investigated using Pearson's correlation and regression analysis. Pearson's correlation is a measure of the linear relationship between two continuous random variables. It does not assume normality, although it does assume finite variances and finite covariance. When the variables are bivariate normal, Pearson's correlation provides a complete description of the association. However, for non-normal populations, the sample correlation coefficient remains approximately unbiased, but may not be efficient. The results in Table 10 show that all managerial competencies are significantly correlated to business profitability. Resource management capabilities has the highest correlation with profitability (Correlation coefficient $=0.743, p=0.000)$, followed by innovation management capabilities (Correlation $=0.732, p=0.000$ ) and lastly marketing management capabilities (Correlation coefficient $=0.695, p=0.000$ ).

The findings on the three managerial capabilities and firm profitability (a component of firm performance) seem to cohere with previous studies. Bridoux (2004) observes some reciprocal interactions at multiple levels of analysis between the business' market environment and firm capabilities, business strategy and performance, and interactions between strategy and performance, which in turn shape both organisational capabilities and competitive environments. Ramorena (2016) supports this view by acknowledging the continual complementarity between firm-level capabilities (internal networking, social capital networks, product innovation) and market-level capabilities (external networking, market innovation) as they relate to small business growth and profitability. 


\section{Regression analysis of the relationship between managerial competencies and the profitability of emerging technology businesses}

To predict the relationship between managerial capabilities and firm profitability and associated effect sizes, a regression analysis was conducted. The results of the regression analysis are illustrated in Table 11.

The regression results in Table 11 show that when considered together, marketing management competencies will have a non-significant influence on profitability (coefficient $=0.121$, $t=1.145, p=0.255$ ). This result may mean that small Internet cafés located in main urban centres (i.e. Bloemfontein) and peri-urban centres (Botshabelo and ThabaNchu) do not necessarily need to market their activities because of their current ideal locational advantages (e.g. proximity to the city, easy accessibility). Alternatively, rather than conceive this relationship from the perspective of limited access to markets, which have been considered to be a main inhibitor of the profitability of South Africa SMMEs (Nieman \& Nieuwenhuizen, 2009), this result may mean that these Internet cafés have already established their goodwill with customers making the marketing of their activities unnecessary.

Resource management capabilities have the most significant influence on profitability (coefficient $=0.513, t=4.191$, $p=0.000$ ). Innovation has the second highest impact on profitability (coefficient $=0.337, t=3.322, p=0.001$ ). Thus, it is clear from these findings that the profitability of the business is a consequence of combinations of entrepreneurial orientation components such as innovation as well as organisational resources. Ferreira, Azevedo and Ortiz (2011) who report that firm resources, personal resources and innovation capabilities are all critical to the growth and profitability of small firms, corroborate this finding. The $R$-square value also shows that the three managerial competencies account for $98.8 \%$ of business growth $(R$-square $=0.988)$.

\section{Implications}

\section{Study implications and research limitations}

The prevalence of women and the limited participation of men in small technology-oriented businesses raise some doubts on the relevance of literature that emphasises the dominance of men in running technology-oriented businesses. Future studies should be conducted at the national level to establish if these gender gaps persist with regard to participation in management of technology-oriented businesses.

TABLE 11: Regression results for the influence of managerial competencies on business profitability.

\begin{tabular}{lcccccc}
\hline Dependent variable $\dagger$ & \multicolumn{2}{c}{ Parameter estimates } & & \multicolumn{2}{c}{ t-tests } \\
\cline { 2 - 3 } \cline { 6 - 7 } & Coefficient & Std. error & & $\boldsymbol{t}$ & $\boldsymbol{p}$ \\
\hline Innovation management capabilities & 0.337 & 0.101 & & 3.322 & 0.001 \\
Marketing management capabilities & 0.121 & 0.105 & & 1.145 & 0.255 \\
Resource management capabilities & 0.513 & 0.123 & & 4.191 & 0.000 \\
\hline
\end{tabular}

$R, 0.995 ; R^{2}, 0.989$

Std., standard.

$\dagger$, Performance and profitability.
The majority of the businesses surveyed were very small establishments, employing less the six employees and had owners or managers with less than six years of experience. The implication of these findings is the need to establish whether the provision of management training to owners or managers from the inception of the business would increase the growth orientation of such businesses. Management training is conceived as critical to the success of emerging businesses (Mpiti, 2016; Rambe \& Mpiti, 2016). This is particularly critical in view of the fact that less than half of the surveyed businesses managed to reach their financial targets in the previous three years, pointing to constrained growth opportunities.

Compared to other innovation management capabilities, employees' involvement in collaborative decision making on stock purchases was comparatively lower than other variables, pointing to some owners' or managers' authoritative tendencies with regard to business management. Future studies may need to compare the performance implications of democratically managed and authoritatively managed businesses. Because only about half of the surveyed businesses explored the size of the market before launching a new product or service, future studies covering market management capabilities of small businesses need to examine the business growth implications of such businesses in comparison to businesses that do not embark on such market exploration.

Because resource management capabilities have the highest correlation with firm profitability, the implication is that small businesses should concentrate more on this dimension compared to other managerial capabilities to improve their competitiveness. Because regression analysis demonstrated that when all managerial competencies were considered collectively, market management competencies did not have a significant influence on firm profitability, it would be more appropriate for firms to concentrate on resource management and innovation management capabilities if their performance is to be optimised.

\section{Conclusion}

The study examined the managerial competencies discernible among small technology-oriented businesses, especially PAVs such as Internet cafés. The study also employed correlation analysis to examine the relationship between such businesses and their level of profitability including which managerial competency has the greatest impact of firm profitability. The study findings demonstrated three sets of managerial competencies, namely, market management, resource management and innovation management capabilities. In terms of their correlations with profitability, resource management capabilities had the highest significant correlation with firm profitability, followed by innovation management, and lastly, marketing management capabilities. When considered collectively, 
market management capabilities could be removed from the capabilities-profitability relationship with little effect. In view of firms' failure to reach their financial targets including somewhat weaker effects of market management capabilities on firm performance, the need to emphasise resource management and innovation management capabilities among resource-constrained emerging firms cannot be discounted.

\section{Acknowledgements}

The author is grateful to Miss Naledi Makhalemele and her team for assisting with data collection. The author also thanks the statistician for detailed analysis and Dr Agbobli for commenting on the previous versions of the research instrument.

\section{Competing interests}

The author declares that there was no competing interest in the production of this article.

\section{References}

Agbobli, E. K. (2013). The influence of entrepreneurial and market orientations on small scale rural agricultural enterprises in the Vryburg area ( $\mathrm{PhD}$ thesis). Central University of Technology.

Alcantar, J., \& Ngwenyama, O. (2015). Top management capabilities for SME's market entry decisions. International Association for Management of Technology IAMOT 2015 Conference Proceedings, 8-11 June 2015. Cape Town, South Africa.

Allen, P. (2013). Complexity, uncertainty and innovation. Economics of Innovation and New Technology, 22, 702-725. https://doi.org/10.1080/10438599.2013.795776

Aylin, A., Garango, P., Cocca, P., \& Bititchi, U. (2013). The development of SME managerial practice for effective performance management. Journal of small business and enterprise development, 20(1), 28-54. https://doi.org/10.1108/ 14626001311298402

Banterle, A., Cavaliere, A., Stranieri, S., \& Carraresi, L. (2009, September 3-6). Marketing management capabilities and price setting: An empirical analysis in the EU traditional food sector. Paper prepared for presentation at the 113th EAAE Seminar 'A resilient European food industry and food chain in a challenging world,' Chania, Crete, Greece.

Barney, J. B., \& Hesterly, W. S. (2006). Strategic management and competitive advantage. Upper Saddle River, NJ: Pearson Education.

Barosa, A., \& Cintra, L. (2012). Innovation, competencies and organizational performance - Articulating constructs and their operational capability. Future Studies Research Journal, 4(1), 30-59.

Berry, L. (1983). Relationship marketing. In L. Berry, G. Shostack, \& G. Upah (Eds.), Emerging perspectives on service marketing (pp. 25-28). Chicago, IL: American Marketing Association.

Berry, L., \& Parasuraman, A. (1991). Marketing services. New York, NY: The Free Press.

Bharadwaj, A. S. (2000). A resource-based perspective on information technology capability and firm performance: An Empirical Investigation. MIS Quarterly, 24(1), 169-196. https://doi.org/10.2307/3250983

Bouazza, A., Ardjouman, D., \& Abada, O. (2015). Establishing the factors affecting the growth of small and medium-sized enterprises in Algeria. American International Journal of Social Science, 4(2), 101-115.

Braganza, A., Brooks, L., Nepelski, D., Ali, M., \& Moro, R. (2017). Resource management in big data initiatives: Processes and dynamic capabilities. Journal of Business Research, 70, 328-337. https://doi.org/10.1016/j.jbusres.2016.08.006

Brancatisano, G., Jurriëns, J., \& Verburg, R. (2012). Competence-based approach for small and medium-sized enterprises: For selecting suitable international marketentry strategies. Has Business Publications, 8, 137-155.

Bridoux, F. A. (2004). Resource-based approach to performance and competition: An Overview of the Connections between Resources and Competition. Retrieved from

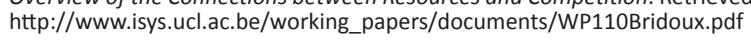

Butler, C. (2016). ZAR insights from Chuck Butler. Retrieved from http://www. everbank.com/currencies/south-african-rand/insights

Carland, W. J., Hoy, F., Boulton, W. R., \& Carland, J. C. (2007). Differentiating entrepreneurs from small business owners: A conceptualization. In Á. Cuervo, D. Ribeiro, \& S. Roig (Eds.), Entrepreneurship (pp. 73-81). Berlin: Springer.

Chen, J., Paik, M., \& McCabe, K. (2014, July 9-11). Exploring internet security perceptions and practices in urban Ghana. Symposium on Usable Privacy and Security (SOUPS), Menlo Park, CA.
Christopher, M. (2003). Logistics and supply chain management: Strategies for reducing cost and improving service. London: Pitman Publishing.

Cohen, L., Manion, L., \& Morrison, K. (2010). Research methods in education. Oxon: Routledge.

Construction Industry Development Board (CIDB) Quarterly Monitor. (2015). Progress against Construction Industry Indicators. Pretoria: CIBD.

Coviello, N. E., Brodie, R. J., Danaher, P. J., \& Johnston, W. J. (2002). How firms relate to their markets: An empirical examination of contemporary marketing practices. Journal of Marketing, 66(3), 33-46. https://doi.org/10.1509/jmkg.66.3.33.18500

Cragg, P. B. (2002). Benchmarking information technology practices in small firms. European Journal of Information Systems, 11(4), 267-282. https://doi.org/ 10.1057/palgrave.ejis.3000430

Cragg, P. (2008). Identifying key Information Systems competencies in smal firms. Total Quality Management, 19(1-2), 29-35. https://doi.org/10.1080/ 14783360701601926

Dammert, A., Galdo, J., \& Galdo, V. (2014). Mobile phones for labour market intermediation: A multi-treatment experimental design. Retrieved from http:// conference.iza.org/conference_files/worldb2014/galdo_j2620.pdf

Day, G. (1994). The capabilities of market-driven organizations. Journal of Marketing, 58(4), 37-52. https://doi.org/10.2307/1251915

Dierckx, I. \& Cool, K. (1989). Asset stock accumulation and sustainability of competitive advantage. Management Science, 35, 1504-1511. https://doi.org/10.1287/ mnsc.35.12.1504

Dubey, R., \& Ali, S. S. (2011). Study on effect of functional competency on performance of Indian manufacturing sector. International Journal of Engineering Business Management, 3, 1-15. https://doi.org/10.5772/50941

Dzansi, D., Rambe, P., \& Coleman, W. (2015). Enhancing new venture creation success in South Africa: A project management perspective. Problems and Perspectives in Management, 13(2), 417-425

Dzansi, D. Y. (2014). Research methodology module 1. Bloemfontein: Central University of Technology.

Field, A. (2009). Discovering statistics using SPSS. London, UK: Sage.

Fejfarová, M., \& Urbancová, H. (2015). Application of the competency-based approach in organisations in the Czech Republic. Business Administration and Management, 1(18), 111-121. https://doi.org/10.15240/tul/001/2015-1-009

Ferreira, J. J., Azevedo, S. G., \& Ortiz, R. F. (2011). Contribution of resource-based view and entrepreneurial orientation on small firm growth. Journal of International Business Administration, 11(1), 95-116.

Furuholt, B., \& Kristiansen, S. (2007). Internet Cafés in Asia and Africa - Venues for education and learning? The Journal of Community Informatics, 3(2), Retrieved from http://ci-journal.net/index.php/ciej/article/view/314/320

Grant, R. M. (1991). The resource-based theory of competitive advantage: Implications for strategy formulation. California Management Review, 33(3), 114-135. https:// doi.org/10.2307/41166664

Gruber, M. (2007). Uncovering the value of planning in new venture creation A process and contingency perspective. Journal of Business Venturing, 22(6) 782-807. https://doi.org/10.1016/j.jbusvent.2006.07.001

Gumbochuma, J. (2017). The status and impact of technology transfer and innovation on the productivity and competitiveness of small-scale agro processing businesses in Mashonaland Central (Zimbabwe) and Free State (South Africa) (Unpublished doctoral thesis), Central University of Technology, Free State, South Africa.

Hansson, P. O., \& Wihlborg, E. (2011). Internet café as a supportive educational arena - A case study from the urban slum of Kibera, INTED 2011 Conference Proceeding (pp. 5966-5975). Nairobi, Kenya.

Hatten, T. S. (2006). Small business management: Entrepreneurship and beyond (3rd ed.). Boston, MA: Houghton Mifflin Company.

Hou, J.-J., \& Chien, Y.-T. (2010). The effect of market knowledge management competence on business performance: A dynamic capabilities perspective. International Journal of Electronic Business Management, 8(2), 96-109.

Hsu, Y.-C., \& Chuang, O. (2008). Are Internet Cafés gendered spaces? Cyberpsychology and Behaviour, 11(2), 224-226. https://doi.org/10.1089/cpb.2007.0051

Ingram, P., \& Simons, T. (1995). Institutional and resource dependence determinants of responsiveness to work-family issues. The Academy of Management Journal, $38,1466-1482$

Jaworski, B. J., \& Kohli, A. K. (1993). Market orientation: Antecedents and consequences. Journal of Marketing, 57, 53-70. https://doi.org/10.2307/1251854

Jauhari, V. (2006). Competencies for a career in the hospitality industry: An Indian perspective. International Journal of Contemporary Hospitality Management, 18, 123-134. https://doi.org/10.1108/09596110610646673

Jerald, C. D. (2009). Defining a 21st century education. Alexandria, VA: Centre for Public Education.

Kandampully, J. (2002). Innovation as the core competency of a service organisation: The role of technology, knowledge and networks. European Journal of Innovation Management, 5(1), 18-26. https://doi.org/10.1108/14601060210415144

Kohli, A. K., \& Jaworski, B. J. (1990). Market orientation: The construct, research propositions. Journal of Marketing, 54, 1-19. https://doi.org/10.2307/1251866

Königová, M., Urbancová, H., \& Fejfar, J. (2012). Identification of managerial competencies in knowledge-based organisations. Journal of Competitiveness, $4(1), 129-142$. 
Kotler, P. (2004). Marketing management. Upper Saddle River, NJ: Prentice Hall.

Krajcovicova, K., Caganova, D., \& Cambal, M. (2012). Key managerial competencies and competency models in industrial enterprises. Annals of DAAAM for 2012 and Proceedings of the 23rd International DAAAM Symposium, Zadar, Croatia, 23(1), 1119-1122.

Laakso-Manninen, R., \& Viitala, R. (2007). Competence management and human resource development: A theoretical framework for understanding the practices of moder Finnish organisations. Helsinki: HAAGA-HELIA University of Applied Sciences.

Liang, Q., Huang, Z., Lu, H., \& Wang, X. (2015). Social capital, member participation, and cooperative performance: Evidence from China's Zhejiang. International Food and Agribusiness Management Review, 18(1), 49-78.

Lindgren, M., \& Packendorff, J. (2011). On the temporary organizing of entrepreneurial processes: Applying a project metaphor to the study of entrepreneurship. Revue De. Entrepreneuriat, 10(2), 45-67. https://doi.org/10.3917/entre.102.0045

Mahoney, J. T., \& Pandian, J. R. (1992). The resource-based view within the conversation of strategic management. Strategic Management Journal, 13(5), 363-380. https://doi.org/10.1002/smj.4250130505

Makhalemele. (2016). The relationship between managerial competencies and performance of SMMEs: A case of internet cafés in the Mangaung Metropolitan Area in South Africa (Unpublished master's thesis), Central University of Area in South Africa (Unpublished
Technology, Free State, South Africa.

Maveé, N., Perrelli, R., \& Schimmelpfennig, A. (2016). Surprise, surprise: What drives the rand/U.S. dollar exchange rate volatility? IMF Working Paper, WP/16/205 Washington, DC: International Monetary Fund.

Moshavi, D., \& Koch, M. (2005). The adoption of family-friendly practices in familyowned firms. Community, Work \& Family, 8(3), 237-249. https://doi.org/ $10.1080 / 13668800500142210$

Mpiti, N. (2016). The influence of private and public finance on the performance of SMMEs in the Free State: A case of Afro hair salons in Mangaung Metropolita Area. Unpublished master's thesis, Central University of Technology, Free State, South Africa.

Narver, J. C., \& Slater, S. E. (1990). The effect of a marketing orientation on business profitability. Journal of Marketing, 54, 20-35. https://doi.org/ 10.2307/1251757

Ndofirepi, T. (2016). The impact of technological creativity and entrepreneurship education on the entrepreneurship intentions of students at particular tertiary institutions in Zimbabwe and South Africa (Unpublished doctoral thesis), Centra University of Technology, Free State, South Africa.

Nguyen, T. M. (2008). Functional competencies and their effects on performance of manufacturing companies in Vietnam. Fribourg: University of Fribourg.

Nkosi, E., Bounds, M., \& Goldman, G. (2013). Skills required for the management of Black-owned small enterprises in Soweto. Acta Commercii, 13(1). https://doi. org/10.4102/ac.v13i1.186

Nieman, G., \& Nieuwenhuizen, C. (2009). Entrepreneurship: A South African perspective (2nd ed). Cape Town: Van Schaik Publishers.

Nolan, C., Conway, E., Farrell, T., \& Monks, K. (2010). Competency need in Irish hotels: Employer and graduate perspectives. Journal of European Industrial Training, 31 432-454. https://doi.org/10.1108/03090591011049800

Olawale, F., \& Garwe, D. (2010). Obstacles to the growth of new SMEs in South Africa: A principal component analysis approach. African Journal of Business Management, 4(5), 729-738.

Oleksyn, T. (2010). Zarzqdzanie kompetencjami. Teoria i praktyka. Warszawa: Oficyna Wolters Kluwer Business.

State of North Dakota. (n.d.). Competency Library. (online). Retrieved from https:// www.nd.gov/omb/sites/omb/files/documents/.../nd-competency-library.pdf

Peppard, J., \& Ward, J. (2004). Beyond strategic information systems: Towards an IS capability. Journal of Strategic Information Systems, 13, 167-194. https://doi. org/10.1016/j.jsis.2004.02.002

Pietersen, J. \& Maree, K. (2014). Standardisation of a questionnaire. In K. Maree (Ed.) First steps in research (pp. 215-222). Pretoria: Van Schaik Publishers.

Powell, A. (2007). An ecology of public internet access: Exploring contextual internet access in an urban community. The Electronic Journal of Communication, 17/1 \& 2), Retrieved from http://www.cios.org/EJCPUBLIC/017/1/01715.HTML

Privitera, G. J. (2013). Research methods for the behavioural sciences. Los Angeles, CA: Sage Publications.

Punch, K. F. (2013). Introduction to social research: Quantitative and qualitative approaches. London: Sage.

Rambe, P. (2013). Converged social media: Identity management and engagement on Facebook mobile and blogs. Australasian Journal of Educational Technology, 29(3), 315-336. https://doi.org/10.14742/ajet.117
Rambe, P., \& Dzansi, D., (2016). Informal distributed leadership in technology adoption. African Journal of Science, Technology, Innovation and Development, 8(2), 155-165. https://doi.org/10.1080/20421338.2016.1147200

Rambe, P., \& Makhalemele, N. (2015). Relationship between managerial competencies of /managers of emerging technology firms and business performance: A conceptual framework of internet cafés performance in South Africa. International Business \& Economics Research Journal, 14(4), 1-14. https://doi.org/10.19030/ iber.v14i4.9357

Rambe, P., \& Mokgosi, B. (2016). The influence of personal, family and social variables on technology-oriented venture creation: Theoretical case of internet cafés in Bloemfontein, South Africa. The Journal of Applied Business Research, 34(4) 1063-1078. https://doi.org/10.19030/jabr.v32i4.9722

Rambe, P., \& Mpiti (2016). The influence of private and public finance, organisational and environmental variables on the performance of beauty salons in the Free State, South Africa: A theoretical perspective. International Business and Economics Research, 16(1), 1-18.

Ramirez-Portilla, A. (2013, January 16-18). Project manager's characteristics influence in the entrepreneurial process: A project based entrepreneurship model. Paper presented at the DRUID Academy, Comwell Rebild Bakker, Rebild/Aalborg, Denmark.

Ramorena, M. (2016). The impact of social networks on innovation, competitiveness and firm performance in the South African context: A case study of emerging construction firms in the Free State, (Unpublished doctoral thesis), Central University of Technology, Free State, South Africa.

Ritter, T. (n.d.). Market management capabilities of vusiness-to-business firms. Frederiksberg. Denmark: Copenhagen Business School. Unpublished manuscript. Retrieved from https://www.impgroup.org/uploads/papers/4746.pdf

Selywn, N. (2016). Academic work in the digital age. Transcript of a talk given at the 'Disrupting Higher Education Dialogues' Conference - Deakin University, 'Disrupting Higher Education Dia

Shuman, J. C., \& Seeger, J. A. (1986). The theory and practice of strategic management in smaller rapid growth firms. American Journal of Small Business, 11(1), 7-18. https://doi.org/10.1177/104225878601100101

Statistics South Africa's General household survey (GHS). (2014). Retrieved from https://news/telecoms/127450-internet-access-in-south-africa-best-and-worstprovinces.html

Szczepańska-Woszczyna, (2014). Competencies, innovation and entrepreneurship in the theory and practice of management. Dąbrowa Górnicza, Poland: Scientific Publishing of the University of in Dąbrowa Górnicza.

Quinn, R. E., Faerman, S. R., Thompson, M. P., \& McGrath, M. R. (2007) Profesjonalnezarzqdzanie. Warszawa: PWE.

Tangwo, A. (2012). The impact of motivations, personal values, management skills of managers on the performance of SMEs in selected towns (Port Elizabeth and Port
Alfred) in the Eastern Cape Province, South Africa (Unpublished master's thesis), Alfred) in the Eastern Cape Province,
University of Fort Hare, South Africa.

Temtime, Z., \& Pansiri, J. (2005). Managerial competency and organizational flexibility in small and medium enterprises in Botswana. Problems and Perspectives in Management, 1, 25-36.

United Nations Industrial Development Organisation (UNIDO) (2002). UNIDO competencies: Strengthening organisational core values and managerial capabilities [Online]. Retrieved from http://www.unido.org2002.P.351

Urban, B. (2010). Technology and entrepreneurial orientation at the organisational level in the Johannesburg area. SA Journal of Human Resource Management, 8(1) 1-9. https://doi.org/10.4102/sajhrm.v8i1.212

Van Scheers, L. (2011). SMEs' marketing skills challenges in South Africa. African Journal of Business Management, 5(13), 5048-5056.

Walker, R., Damanpour, F., \& Devece, C. (2011). Management innovation and organizational performance: The mediating effect of performance management.
Journal of Public Administration Research and Theory, 21(2), 367-386. https:// Journal of Public Administration
doi.org/10.1093/jopart/muq043

Wijaya, S., \& Polina, A. (2014). Male and female Internet access usage patterns at public access venues in a developing country: Lessons from Yogyakarta, Indonesia.
The Journal of Community Informatics, 10(1), online. Retrieved http://www.ciThe Journal of Community Informatics, 10(1), on
journal.net/index.php/ciej/article/view/798/1141

Yahya, H., \& Elsayed, K. (2012). The influence of the factors of managerial competencies among SMEs in Selangor, Malaysia: A preliminary study of human resources. Australian Journal of Basic and Applied Sciences, 6(13), 123-134.

Ziębicki, B. (2011). Managerial competencies in the context of contemporary management concepts and methods. pp. 221-239. Retrieved from http:// repozytorium.wsb-nlu.edu.pl/bitstream/handle/11199/7453/Zi\%C4\%99bicki\% 20 Bernard, $\% 20$ Managerial $\% 20$ competencies $\% 20$ in $\% 20$ the $\% 20$ contex $\%$ 20 of $\% 20$ contemporary $\% 20$ management $\% 20$ concepts $\% 20$ and $\% 20$ methods. pdf? sequence $=1$ 